\title{
Analysis of Financial Perfomance Effect on Abnormal Stock Return in the Food and Beverage Companies Listed at Indonesia Stock Exchange
}

\author{
Icasania Septentia ${ }^{1}$, Sri Hastuti ${ }^{2}$, Dwi Suhartini ${ }^{3}$, Tri Kartika Pertiwi ${ }^{4}$ \\ \{icasania15@gmail.com ${ }^{1}$, suhartinidwi7@gmail.com ${ }^{3}$, kartika_tiwi@yahoo.co.id ${ }^{4}$ \} \\ ${ }^{1}$ Student of Magister Accounting UPN "Veteran" Jawa Timur, Indonesia \\ ${ }^{2,3,4}$ Lecturer Faculty of Economics UPN “Veteran" Jawa Timur, Indonesia
}

\begin{abstract}
Investment decisions in stock exchange need a various informations, one of those which related to the condition of company that showed in financial statement for understanding the financial information. One of methods for knowing that the financial information may be useful in predicting the price or the share return is to make financial ratio analysis. Return used in this research was the abnormal return share, that is, a difference between the realization return and the expected return or the expectation return.The writer conducted this research at the food and beverage companies have been listed at Indonesian Stock Exchange. The method used in sample collection was the purposive sampling, while the data was secondary data involving financial statement data and company stock price. Data analysis used was multiple linear regression analysis for assessing the effect of earning per share, current ratio, debt to equity ratio, on the abnormal return share.From the analysis results it was resulted that the multiple linear regression model used was not fit due. Independent variable earning per share, current ratio, fixed assets turnover ratio had no effect on the abnormal stock return, only the debt to equity ratio variable has a significant effect on abnormal stock return.
\end{abstract}

Keywords:Earning Per Share, Current Ratio, Debt To Equity Ratio And Fixed Assets Turnover Ratio On The Abnormal Stock Return

\section{Introduction}

The organization of sustainable national development needs quite much fund where the fulfillment cannot only rely on the source from the government, but the aids from companies that go public are also needed to expedite the activities of economy development.

One of the sources of fund that can be obtained by a company is by selling its shares to public in capital market. The capital market in Indonesia is Indonesian Stock Exchange that can be the medium of meeting between investor and issuer. Besides that, capital market can support the realization of efficient fund allotment because with the presence of capital market the investor can choose investment alternatives that can give the most optimal returns. Capital 
market that can be said to operate well is certainly a capital market that is efficient in its operational activities (Jogiyanto, 2000)

Stock price can be said to be the indicator of company management success, where market power is indicated by the presence of company share trade transaction in capital market. The occurrence of transaction is based on the result of observation by investors on company achievement in producing profit that increase the demand on the concerned company so the market price of stock will also increase and can also increase stock returns. If the situation that occurs is otherwise, it will decrease the market price of share of the concerned company that decrease share returns.

An important information for investors in taking decision of investment in capital market is by obtaining various types of information including information related to company performance and other technical information. Financial information related general condition of company is indicated in financial statement that will give many benefits if the it is analyzed further before utilized as an aid of decision making. It is in accordance with the study conducted by Lev and Thiagajaran (1993) in (Meriewaty \& Setyani, 2005) that states that financial statement is required to understand financial statement.

While for the concept of returns, there are many concepts such as Zainuddin and Jogiyanto (1999) who differentiate the concept of returns into two groups namely single return and portfolio return. Single return is the result obtained from investment in form of realized return and expected return. Realized return is the return that takes place and is calculated based on historical data and functions as one of measurements of company performance. Historical return is also useful as the determining basis of expected return in the future. Expected return is the return expected to be obtained by investors in the future (Jogiyanto, 2000)

One of the ways to measure stock returns is by using share abnormal return, namely the difference between realization return and expected return. Realization return is the difference with previous price of share, while expected return can be generated using Market Adjusted Model that can be obtained by subtracting previous combined price index of share from current combined price index of share.

An empirical study using financial statement connected to share returns was conducted by (Wahyuni, 2002) that examined whether financial ratio based on data of cash flow report had additional information. Other finding showed that cash flow ratio had additional information. Other finding showed that financial ratio was useful in predicting changes of profits in the next one year and balance ratio had a higher prediction ability that cash flow ratio. Zainuddin and Jogiyanto (1999) tested the benefits of accounting information in predicting profit growth of banking companies that showed that construct ratio of capital finance, assets, earning, and liquidity were significant in predicting profit growth for the next one year, and while for financial ratio of financial level, the test result showed that there was no significant financial ratio in predicting profit of banking companies for the next two years. Parawiyati (2000) investigated the use of financial information to predict profits for investors in capital market. The test result showed that the financial information variable had significant effect as the predictor of profit and cash flow for the next one, two, up to four years.

Food and beverage industry in Indonesia that grows extraordinarily apparently triggers the implication of more players participating in the industry. In the market, almost in every food and beverage market segment, there are more players that can be seen from the fact that every month there is information of new product that appears in the market. Not only the competition gets stricter, the characteristics of food and beverage market get more difficult to penetrate, more challenges, and if it is not responded by appropriate strategy, it will be a threat that results in failure (www.swa.co.id 19 February 2009). Therefore, the use of food and beverage 
companies as the research object was because the shares coming from food and beverage products were the shares mostly demanded by investors, because the basic needs of people are always consumed every time.

In the last few months, the effect of global crisis has penetrated all of national economic joints. Almost no countries that are not affected by the crisis, including Indonesia and China, have strong economy. In Indonesia, serious effect has occurred in capital marketing since a few months ago. Many companies entering capital market were bankrupt because their protuberant share value finally shrank that disturbed the financial system. Real sectors could not move well either. The growth of industrial sector was also a serious problem. Even deindustrialization occurred because many industrial sub-sectors experienced extremely low and negative growth (Jawa Pos, 16 March 2009).

Based on the explanation above, the study aimed to investigate market efficiency viewed from market reaction after the issuance of financial statement. Market reaction was indicated by changes of price of the concerned securities. The reaction could be measured using share abnormal return. The financial analysis used in investigating financial performance was Earning per Share, Current Ratio, Debt to Equity Ratio, and Fixed Asset Turnover Ratio.

\section{Return Stock}

Return is the income that is entitled to investors because of investing funds in the form of shares (Jogiyanto, 2000). As a rational investor, stock returns are very important and that profits or losses can be monitored to obtain business certainty. (Tandelilin, 2001) return is one of the factors that motivates investors to invest and is also a reward for the courage of investors to endure the risk of their investments.

Returns can be realized returns that have already occurred or expected expectations that have not yet occurred but are expected to occur in the future. Realized returns are calculated based on historical data. Realized returns are important because they are used as a basis for determining expected returns and future risks.

\section{Definition and Measurement of Abnormal Stock Returns}

(Jogiyanto, 2000), abnormal return or excess return is the excess of real returns that occur against normal returns. Normal returns is a expectation return. Abnormal return is the difference between the actual return that occurs with the expected return, expressed in the formula as :

$$
\operatorname{ARS}_{i, t}=R_{i, t}-E\left[R_{i, t}\right]
$$

Explanation :

$\mathrm{ARS}_{\mathrm{i},} \quad$ : Abnormal stock return securities for-i in period for- $\mathrm{t}$

$\mathrm{R}_{\mathrm{i}, \mathrm{t}} \quad$ : Real return which happens for securities for-i in period for- $\mathrm{t}$

$E\left[R_{i, t}\right]:$ Expectation return securities for-i period for- $t$

Financial ratios in measuring Abnormal Stock Return 


\section{Earning per share}

Earning per share is one of the profitability ratio, which shows the company's ability to generate profits. Comparison between the amount of earnings (in this case net income that is ready to be distributed to shareholders) with the number of shares of the company, will be obtained components of earnings per share.

For long-term investors, it will be very interested in this analysis, for example, for shareholders, they will see profits that will actually be received in the form of dividends (Sari, Achsani, \& Sartono, 2017). Although the company does not include the amount of earnings per share (EPS) of the company concerned in its financial statements, we can calculate based on the information on the balance sheet and income statement. (Tandelilin, 2001) formula for calculate Earning Per Share

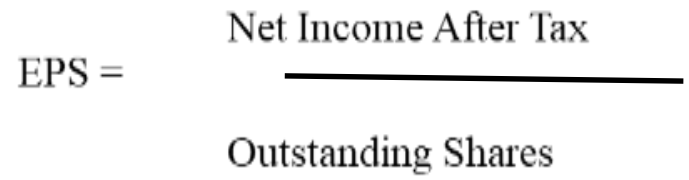

It can be concluded that EPS is a ratio that measures how much net income the company generates for each outstanding share.

\section{Current Ratio}

Current Ratio is one of the liquidity ratios that is generally used to determine the ability to meet short-term obligations. This ratio shows how far the demands of short-term creditors are met by assets that are estimated to be cash in the same period as the debt maturity.

(Sari et al., 2017) this ratio is calculated by dividing current assets by current debt, Formula for calculate Current ratio :

\section{Assets}

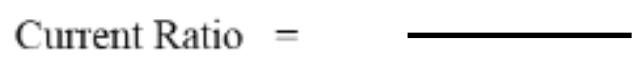

Liabilities

\section{Debt to Equity Ratio}

Debt to Equity Ratio is one of the leverage ratios used to assess the amount of debt used by companies (Koerniawan, 2007). Leverage ratio shows the proportion of the use of debt to finance its investment. Companies that do not have leverage means using $100 \%$ of their own capital. . This ratio can be stated in the following formula :

Total Liabilities

\section{$\mathrm{DER}=$}

Shareholders Equity 
Creditors are generally glad if this ratio is low. The lower the ratio means the higher level of company spending provided by shareholders and the greater the level of protection of creditors from losing money invested in the company.

\section{Fixed Assets Turnover Ratio}

Fixed Asset Turnover ratio is one of the asset ratios. This ratio is used in showing how a company uses its fixed assets such as buildings, vehicles, machinery, office equipment. One of the goals of managers how resources have been used optimally, then by comparing the activation ratio with industry standards, it can be seen the level of efficiency of the company in the industry. Fixed assets turnover ratio, is the ratio between sales and net fixed assets.

Eurene Brigham (2001:83) formula for Fixed assets turnover ratio :

\section{Sales}

\section{Fixed Assets Turnover Ratio $=$ \\ Net Assets}

This ratio indicate the number of times the value of an asset rotates when measured by sales volume. The higher this ratio the better. This means that the ability of fixed assets to create high sales. 


\section{Framework}

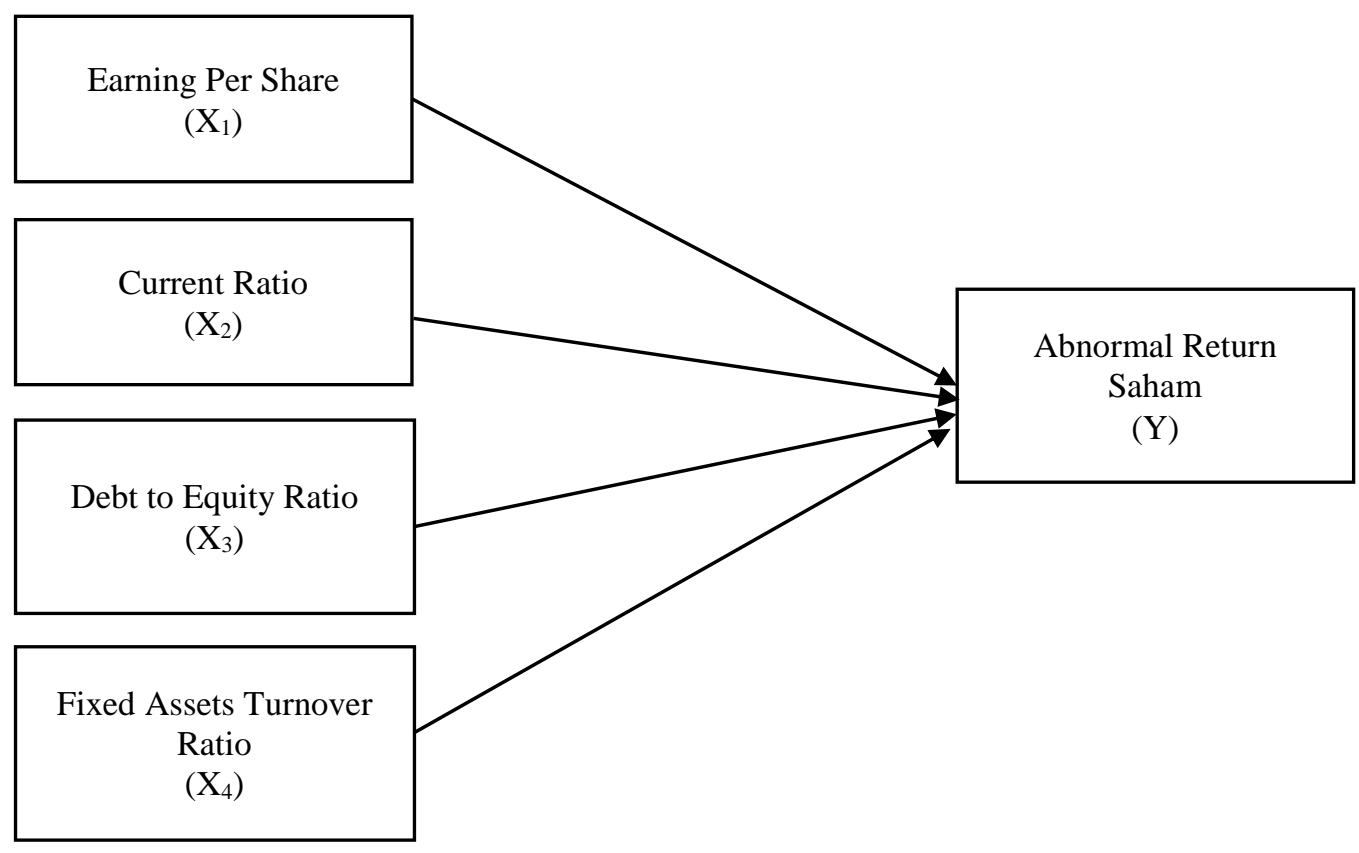

\section{Hypothesis}

Based on the problems and premises that have been described above, the hypotheses proposed in this study are: Financial Perfomance (Earning per share, current ratio, debt to equity ratio, fixed assets turnover ratio) has an impact on abnormal stock returns on food and beverage companies listed on the Indonesia Stock Exchange.

\section{Research Method}

\section{Population and Sample}

The population used in this study is the financial statements of food and beverage companies that go public and make an initial offer on the Bursa Efek Indonesia (BEI). Amount of food and beverage companies listed on the BEI included 19 companies during the 2005-2007 period.

The technique used to determine the sample in this study is purposive sampling, a non-probability sampling technique that selects respondents. The criteria for consideration are :

1. Food and beverage companies that publish financial statements in full for three consecutive years in the 2005-2007 period.

2. Food beverage companies listed on the BEI that make a profit. 


\section{Analysis Technique}

The analysis technique used in this research is quantitative analysis with multiple linear regression formula used to determine the dependence of the dependent variable $(\mathrm{Y})$ on the independent variable $(\mathrm{X})$, with the following formula :

$$
Y=\beta_{0}+\beta_{1} X_{1}+\beta_{2} X_{2}+\beta_{3} X_{3}+\beta_{4} X_{4}+\varepsilon
$$

(Djarwanto, 2001:304)

Explanation :

$\begin{array}{ll}\mathrm{Y} & : \text { Abnormal Return Saham } \\ \beta_{0} & : \text { Konstanta } \\ \beta_{1}, \beta_{2}, \beta_{3}, \beta_{4} & : \text { Koefisien regresi variabel } \mathrm{X}_{1}, \mathrm{X}_{2}, \mathrm{X}_{3}, \mathrm{X}_{4} \\ \mathrm{X}_{1} & : \text { Earning per share } \\ \mathrm{X}_{2} & : \text { Current Ratio } \\ \mathrm{X}_{3} & : \text { Debt to Equity Ratio } \\ \mathrm{X}_{4} & : \text { Fixed assets Turnover Ratio } \\ \varepsilon & : \text { error }\end{array}$

The variables used in this study consisted of the dependent variable (Y) Abnormal Stock return, and independent variable $(\mathrm{X})$ :

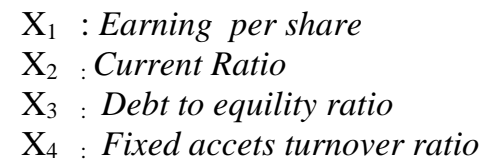

\section{Hypothesis test}

The hypothesis is a theoretical proportion or explanation of some events that can be justified or refuted empirically (Hasan, 2002:50)

a) $\mathbf{F}$ Test

To test the research hypothesis the simultaneous effect of the variable $(\mathrm{X})$ on the variable $(\mathrm{Y})$ is used the $\mathrm{F}$ test with the following procedure:

a. Hipotesis

$\mathrm{H}_{0}: \beta_{1}=\beta_{2}=\beta_{3}=\beta_{4}=0$

(Regresion models do not match)

$\mathrm{H}_{1}: \beta_{1}=\beta_{2}=\beta_{3}=\beta_{4} \neq 0$

(Regresion models match)

b. Level of significant $(\alpha)=0,05$

c. Provisions test :

1. If the significant level (p-value)> 0.05 then $\mathrm{H} 0$ is accepted and $\mathrm{H} 1$ is rejected

2. If the significant level (p-value) $<0.05$ then $\mathrm{H} 0$ is rejected and $\mathrm{H} 1$ is accepted 


\section{b) t Test}

The hypothesis of this study was tested or could not be seen from the results of the $t$ test, because the $t$ test could be used to test whether or not the effect of partially independent variables on the dependent variable was used t test with the following formula:

a. Hipotesis

$\mathrm{H}_{0}: \beta_{\mathrm{i}}=0$ (Partial there can be no influence of independent variables on the dependent variable

$\mathrm{H}_{\mathrm{i}}: \beta_{\mathrm{i}} \neq 0$ (Partial there is a positive influence of the independent variable on the dependent variable

b. Level of significant $(\alpha)=0,05$

c. Provisions test :

1.If it is significant (p-value) $>0.05$ then $\mathrm{H} 0$ is accepted and $\mathrm{H} 1$ is rejected.

2.If it is significant ( $\mathrm{p}$-value) $<0,05$ then $\mathrm{H}_{0}$ is rejected dan $\mathrm{H}_{1}$ is accepted

\section{Result and Discussion}

\section{Equation of Multiple Linear Regression}

The data analysis method used in this study is multiple linear regression analysis used:

\begin{tabular}{|l|r|}
\hline \multicolumn{1}{|c|}{ Model } & \multicolumn{1}{|c|}{ Koefisien regresi } \\
\hline Konstanta & $-0,024$ \\
Earning per Share $\left(\mathrm{X}_{1}\right)$ & 0,00006665 \\
Current ratio $\left(\mathrm{X}_{2}\right)$ & 0,004 \\
Debt to equity ratio $\left(\mathrm{X}_{3}\right)$ & 0,009 \\
Fixed assets turnover ratio $\left(\mathrm{X}_{4}\right)$ & $-0,001$ \\
\hline
\end{tabular}

The resulting multiple linear regression equation is as follows:

$$
Y=-0,024+0,00006665 X_{1}+0,004 X_{2}+0,009 X_{3}-0,001 X_{4}
$$

from the regression equation above explains that : Konstanta (a) generated -0,024 indicates the magnitude of abnormal stock returns $(\mathrm{Y})$, if the earnings per share $\left(\mathrm{X}_{1}\right)$, current ratio $\left(\mathrm{X}_{2}\right)$, debt to equity ratio $\left(\mathrm{X}_{3}\right)$, and fixed assets turnover ratio $\left(\mathrm{X}_{4}\right)$ are constant.

\section{Hypotesis Test}

\section{Result F test}

\begin{tabular}{|l|l|l|l|}
\hline Model & $\mathrm{F}_{\text {calculate }}$ & Sig & $\mathrm{R}^{2}$ \\
\hline Earning per share $\left(\mathrm{X}_{1)}\right.$ & 1,452 & 0,242 & 0,162 \\
Current ratio $\left(\mathrm{X}_{2)}\right.$ & & & \\
Debt to Equity Ratio $\left(\mathrm{X}_{3)}\right.$ & & & \\
Fixed assets Turnover ratio & & & \\
$\left(\mathrm{X}_{4}\right)$ & & & \\
\hline
\end{tabular}




\section{Result t test}

\begin{tabular}{|l|l|l|}
\hline Independent variable & $\mathrm{B}$ & Sig \\
\hline Earning per share $\left(\mathrm{X}_{1)}\right.$ & 0,0000665 & 0,342 \\
Current ratio $\left(\mathrm{X}_{2)}\right.$ & 0,004 & 0,113 \\
Debt to Equity Ratio $\left(\mathrm{X}_{3)}\right.$ & 0,009 & 0,078 \\
Fixed assets Turnover ratio $\left(\mathrm{X}_{4}\right)$ & $-0,001$ & 0,527 \\
\hline
\end{tabular}

\section{Discussion}

This study shows that the multiple linear regression model used is not suitable, so it can be concluded that the earnings per share variable, current ratio, debt to equity ratio and fixed asset turnover ratio do not effect the abnormal stock returns. This can be chosen from the results of the $\mathrm{F}$ test and the coefficient of determination, from the values of the coefficient of determination shows that the earnings per share variable, current ratio, debt to equity ratio and fixed asset turnover ratio variable has a very low influence on abnormal stock returns that is equal to $16.2 \%$ while the remaining $83.8 \%$ is influenced by other factors that are not discussed in this study, such as: assets, equity, liability, sales, net income and others.

While seen from the t test results are obtained :

1. Earning per share $\left(\mathrm{X}_{1}\right)$ variable has no significant to abnormal stock returns grade Sig 0,342 > 0,05. Cash flow information, the company's financial position, and capital changes are potential sources that can be used by investors in making decisions, investors consider that Earning per Share information is less relevant for making economic decisions

2. Current ratio $\left(\mathrm{X}_{2}\right)$ variable has no significant to abnormal stock returns grade Sig $0,113>0,05$. Companies that have high Current Ratio will not necessarily produce high stock returns as well. A high Current Ratio value indicates that the availability of current assets to pay off current liabilities is also high. Whereas current assets contain accounts such as cash and cash equivalents, receivables, inventories and securities. However, the high Current Ratio does not guarantee that the company has enough cash to fulfill the current liabilities.

3. Debt to equity ratio $\left(\mathrm{X}_{3}\right)$ variable has no significant to abnormal stock returns grade Sig $0,078>0,05$. If using $(\alpha) 10 \%(0,1)$ this variable has significant results. This indicates that the use of its own capital for the company is collateral for debt or a part of each equity which is used as collateral for the overall debt of the company. Companies must be able to use their own capital optimally and show the proportion of the use of debt to finance their investments, so they can use the debt to get greater profits.

4. Fixed assets turnover ratio $\left(\mathrm{X}_{4}\right)$ variable has no significant to abnormal stock returns grade Sig $0,527>0,05$. This indicates that the company's ability to use its fixed assets to create low sales. It can reduce the company's performance which has an impact on the decline in the company's stock price. The company must be able to 
use its fixed assets optimally so that it can increase high sales volume by expanding market share

The results of this study support the research of Zainuddin and Jogiyanto (1999), which states that there is no significant financial ratio in predicting profit growth, either for the period of one year ahead or two years into the future. Likewise with the research of Widhy Setyowati (2002) which states that equity growth is the dominant variable for predicting abnormal returns as indicated by the largest beta standard.

\section{Conclussions}

Based on testing the hypothesis using the $\mathrm{F}$ test, it was produced that the of Earning per share $\left(\mathrm{X}_{1}\right)$, Current ratio $\left(\mathrm{X}_{2}\right)$, Debt to equity ratio $\left(\mathrm{X}_{3}\right)$, Fixed assets turnover ratio $\left(\mathrm{X}_{4}\right)$ variable had no effect on abnormal stock returns $(\mathrm{Y})$ food and beverage companiesThen the multiple linear regression model used is not suitable to explain the effect of variables.

While partial hypothesis testing using the $t$ test, it was produced only Debt to Equity Ratio variabel have a significant result on the abnormal stock return. So the research hypothesis which states that "It is suspected that financial performance (Earning per share, Current ratio, Debt to equity ratio, Fixed assets turnover ratio) has an influence on the abnormal stock returns in food and beverage companies listed on the Stock Exchange" is untested.

\section{Acknowledgement}

1. The main basis of this study uses previous research conducted abroad, especially in the United States. So that differences in economic and cultural conditions cannot be controlled in the model

2. The company sample used is less specific in grouping so the test results are less than optimal.

3. The effect of Earning per share $\left(\mathrm{X}_{1}\right)$, Current ratio $\left(\mathrm{X}_{2}\right)$, Debt to equity ratio $\left(\mathrm{X}_{3}\right)$, Fixed assets turnover ratio $\left(\mathrm{X}_{4}\right)$ on abnormal stock returns $(\mathrm{Y})$ is only $16.2 \%$, while the remaining $83.8 \%$ is influenced by other factors not discussed in this study.

\section{References}

[1] Brigham, F. Eugene and Joel F. Houston, 2001, Manajemen Keuangan, Buku 1, Edisi Ke Delapan, Terjemahan Staf Editor, Penerbit Erlangga, Jakarta.

[2] Hasan, Iqbal, 2002, Pokok Pokok Materi Metodologi Penelitian dan Aplikasinya, Penerbit Ghalia, Indonesia.

[3] Jogiyanto, H. (2000). Teori Portofolio dan Analisis Investasi (Kedua). Yogyakarta: BPFE.

[4] Keown, Arthur. J, 1999, Dasar Dasar Manajemen Keuangan, Edisi Ketujuh, Terjemahan Djakman, Chaerul D, Penerbit Salemba 4, Jakarta.

[5] Koerniawan, K. A. (2007). Pengaruh Variabel Fundamental Terhadap Harga Saham Perusahaan Perbankan Di Bursa Efek Jakarta. Jurnal Ekonomi MODERNISASI.

[6] Meriewaty, D., \& Setyani, A. Y. (2005). Analisis Rasio Keuangan Terhadap Perubahan Kinerja Pada Perusahaan di Industri Food and Beverages Yang Terdaftar di BEJ. Akuntansi. 
[7] Sari, L. K., Achsani, N. A., \& Sartono, B. (2017). THE VOLATILITY TRANSMISSION OF MAIN GLOBAL STOCK'S RETURN TO INDONESIA. Buletin Ekonomi Moneter Dan Perbankan. https://doi.org/10.21098/bemp.v20i2.813

[8] Sunariyah, 1997, Pengantar Pengetahuan Pasar Modal, Penerbit UPP AMP YKPN, Yogyakarta

[9] Tandelilin, E. (2001). Analisis Investasi dan Manajemen Portofolio. In Analisis Investasi dan Manajemen Portofolioll.

[10] Wahyuni, S. (2002). Analisis Kandungan Informasi Laporan Arus Kas, 17(2), 200-210. 